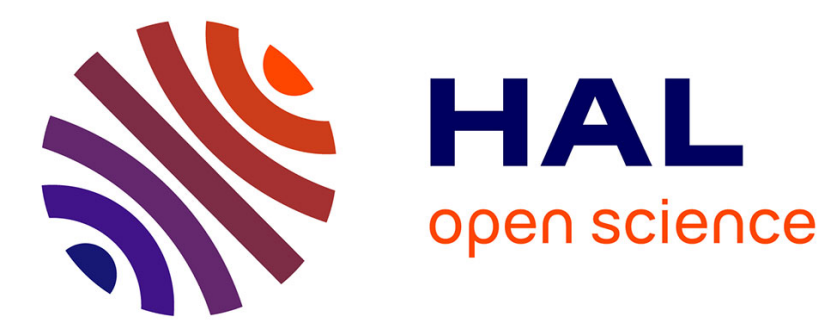

\title{
Present-day deformation in the Upper Rhine Graben from GNSS data
}

Eric Henrion, Frédéric Masson, Cecile Doubre, Patrice Ulrich, Mustapha

Meghraoui

\section{- To cite this version:}

Eric Henrion, Frédéric Masson, Cecile Doubre, Patrice Ulrich, Mustapha Meghraoui. Present-day deformation in the Upper Rhine Graben from GNSS data. Geophysical Journal International, 2020, 223 (1), pp.599-611. 10.1093/gji/ggaa320 . hal-02987540

\section{HAL Id: hal-02987540 \\ https://hal.science/hal-02987540}

Submitted on 14 Oct 2021

HAL is a multi-disciplinary open access archive for the deposit and dissemination of scientific research documents, whether they are published or not. The documents may come from teaching and research institutions in France or abroad, or from public or private research centers.
L'archive ouverte pluridisciplinaire HAL, est destinée au dépôt et à la diffusion de documents scientifiques de niveau recherche, publiés ou non, émanant des établissements d'enseignement et de recherche français ou étrangers, des laboratoires publics ou privés.

\section{(c)(1)}

Distributed under a Creative Commons Attribution| 4.0 International License 


\title{
Present-day deformation in the Upper Rhine Graben from GNSS data
}

\author{
Eric Henrion, Frédéric Masson, Cécile Doubre, Patrice Ulrich and Mustapha Meghraoui \\ IPGS/EOST, Université de Strasbourg/CNRS, 5 rue Descartes, 67084 Strasbourg Cedex, France, E-mail: eric.henrion@unistra.fr
}

Accepted 2020 June 19. Received 2020 June 19; in original form 2019 September 30

\begin{abstract}
A BSTRACT
The Upper Rhine Graben (URG) undergoes continuous microseismicity recorded by seismic monitoring networks and moderate-magnitude earthquakes, such as in the zone north of the Alpine front, which includes the Jura thrust front, the Vosges, the Black Forest, the Swabian Jura and the Alsace plain. The surface velocity field is a good indication of the occurrence and location of strain gradients likely associated with seismogenic structures. To explore that possibility, we use long time-series of displacements measured from 2002 to 2018 with the dense GURN network (GNSS URG Network). The processing based on double differences of phase measurements offers an up-to-date surface velocity field of the URG and surrounding areas. The surface velocity field relative to the Eurasia reference frame (ITR2014) points out some areas where coherent movements are present for groups of stations. The heterogeneous velocity field across the Rhine Graben (Vosges, URG, Black Forest and Swabian Jura) displays velocity values below $0.2 \mathrm{~mm} \mathrm{yr}^{-1}$. We compute a deformation field from the GNSS velocities to link the deformation to the spatial distribution of earthquakes in the Rhine Graben. The earthquakes are concentrated south of an east-west line passing through Strasbourg to the Alpine front. Instrumental and historical seismicity presents spatial similarities in the Vosges and Swabian Jura. Considering the consistent northward movement observed in the Alpine front, we suggest that the strong seismicity in the south of the URG is caused by the shortening of the Alps. North of the URG, the seismicity is more dispersed where the velocity field does not show coherent movements.
\end{abstract}

Key words: Satellite geodesy; Europe; Seismicity and tectonics; Kinematics of crustal and mantle deformation.

\section{INTRODUCTION}

Recent compilations of data acquired by numerous GNSS stations clearly show a strong contrast between the southern and northern regions of Western Europe. South of the Alps, the surface horizontal velocity field is dominated by active tectonics related to the extension in the Tyrrhenian Sea and the Apennines, and by shortening across the eastern part of the Alpine Arc (e.g. Kreemer et al. 2014; Métois et al. 2015). North of the Alps, except for stations affected by the postglacial rebound, the amplitudes of GNSS horizontal velocities with respect to an Eurasian reference frame are relatively small (no larger than $1.0 \mathrm{~mm} \mathrm{yr}^{-1}$, Nocquet 2012).

In this study, we focus on the geodetic signal observed within the Upper Rhine Graben (URG) and surrounding regions, considering its potential relationships to seismic activity. We establish an updated surface velocity field for the URG by processing GNSS data from a dense permanent network over the 2002-2018 period. From GNSS and levelling data, Furhmann et al. (2013) conducted a regional analysis of the URG. Furhmann et al. (2015) focused on the northern part of the URG by combining GNSS, levelling and InSAR data. By computing more recent GNSS data we aim to precisely quantify the surface deformation affecting this region, where horizontal and vertical surface velocities are small and of the same order as their uncertainties. The spatial density determined by the sites of the GNSS Upper Rhine Network (GURN) allows the analysis of geodetic signals over a large area, and the longer period of data recording offers the opportunity to obtain more reliable results.

\section{THE RHINE GRABEN AND ITS SURROUNDING AREAS: SEISMICITY, TECTONIC AND GEODETIC B A C KGROUND}

The European Cenozoic Rift System (ECRIS) extends over $\sim 1000 \mathrm{~km}$ from the North Sea to the Mediterranean coast through Holland, Belgium, Germany, Switzerland and France (Fig. 1a; Ziegler 1992). Its 300-km-long and 40-km-wide central segment, the URG, extends from the Rhenish Massif to the north to the 


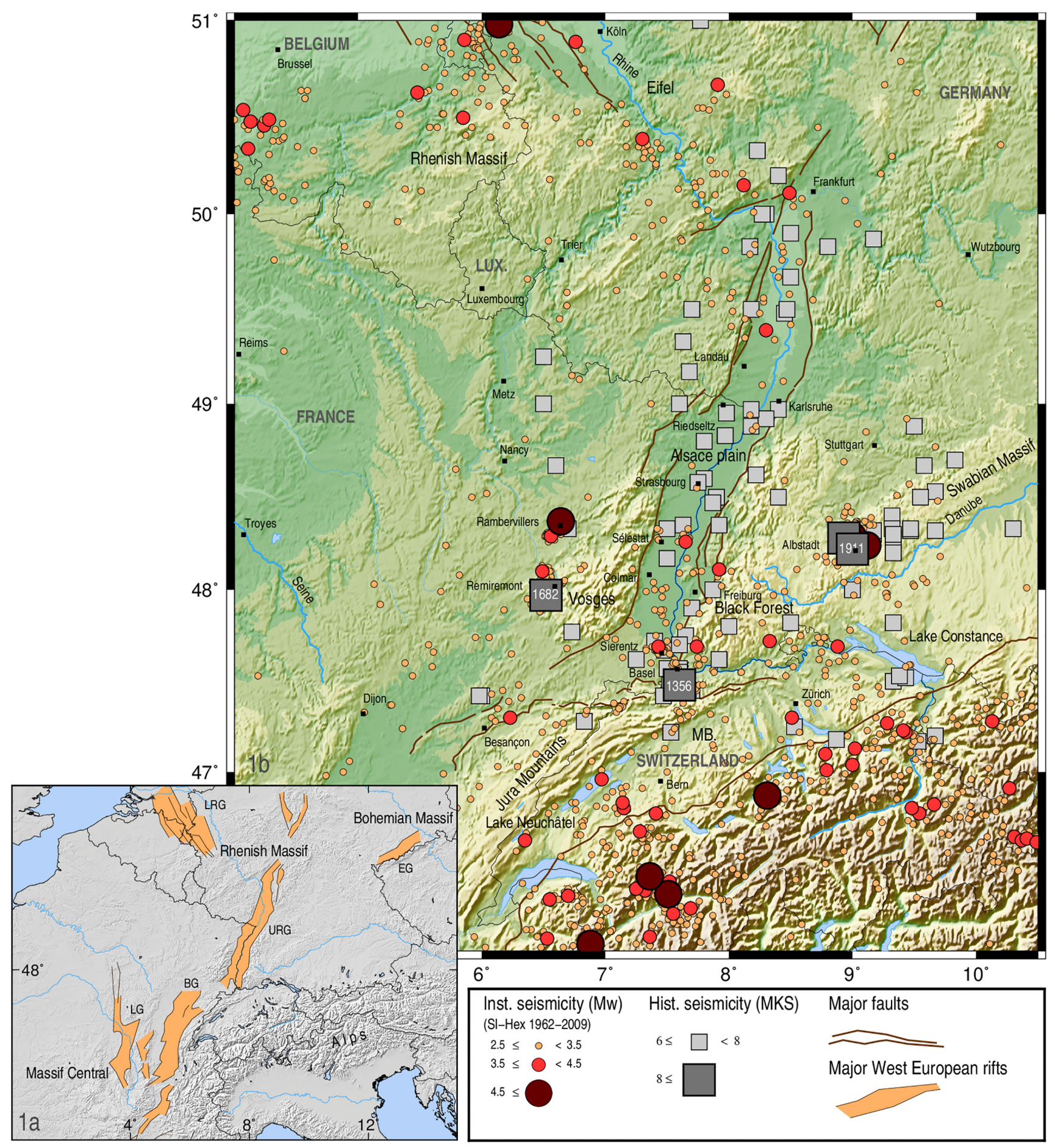

Figure 1. (a) ECRIS, major rifts in orange. (b) Historical and instrumental seismicity (SI-Hex catalogue, Cara et al. 2015) of the URG. In both figures, major faults represented by brown lines. DEM: GTOPO30.

northernmost structural front of the Jura fold-and-thrust belt to the south (Fig. 1b). The graben is bordered to the west by the Vosges Massif and to the east by the Black Forest. Preceded by late Cretaceous volcanism, the rifting was initiated during late Eocene to early Miocene (42-31 Ma) starting with broadly E-W or ENE-WSW extension and lasting until Aquitanian time (23-20 Ma, Ziegler 1992). The southern region of the URG is characterized by a compressive, strike-slip tectonic regime, with a maximum stress axis oriented NW-SE (Delouis et al. 1993; Maury et al. 2014; Heidbach et al.
2016). Long-term deformation associated with Holocene rifting and related to crustal faulting in the Rhine Graben, the Vosges, the Jura thrust front and the Swabian Jura has shaped the topography. At present, geodetic and seismic studies lead us to consider the Western Europe as a stable intraplate continental region. However, moderate-magnitude earthquakes and continuous microseismicity recorded by regional networks regularly affect this region.

The URG is considered to be the most seismically active region of northwest Europe, with moderate earthquakes that have occurred 
Table 1. Instrumental earthquakes in the URG and surroundings areas (index, location, date, time, latitude, longitude, $M_{\mathrm{W}}$ based on the SI-Hex catalogue) with magnitude greater than 4 .

\begin{tabular}{lccccc}
\hline Location & Date & $\begin{array}{c}\text { Time } \\
\text { origin time UTC }\end{array}$ & Latitude & $\begin{array}{c}\text { Longitude } \\
\left({ }^{\circ}\right)\end{array}$ & $\begin{array}{c}M_{\mathrm{w}} \\
\left({ }^{\circ}\right)\end{array}$ \\
\hline Rambervillers & 2003.02 .22 & $20: 41: 07.1$ & 48.37 & 6.64 & 4.9 \\
Sierentz & 1980.07 .15 & $12: 17: 20.9$ & 47.69 & 7.43 & 4.1 \\
Remiremont & 1984.12 .29 & $11: 02: 35.6$ & 48.10 & 6.49 & 4.1 \\
Freiburg & 2004.12 .05 & $01: 52: 39.8$ & 48.11 & 7.92 & 4.4 \\
Balingen & 1969.02 .26 & $01: 28: 01.1$ & 48.29 & 9.00 & 4.7 \\
Ebingen & 1970.01 .22 & $15: 25: 17.0$ & 48.24 & 9.12 & 4.8 \\
Albstadt & 1978.09 .03 & $05: 08: 31.9$ & 48.29 & 8.96 & 5.1 \\
\hline
\end{tabular}

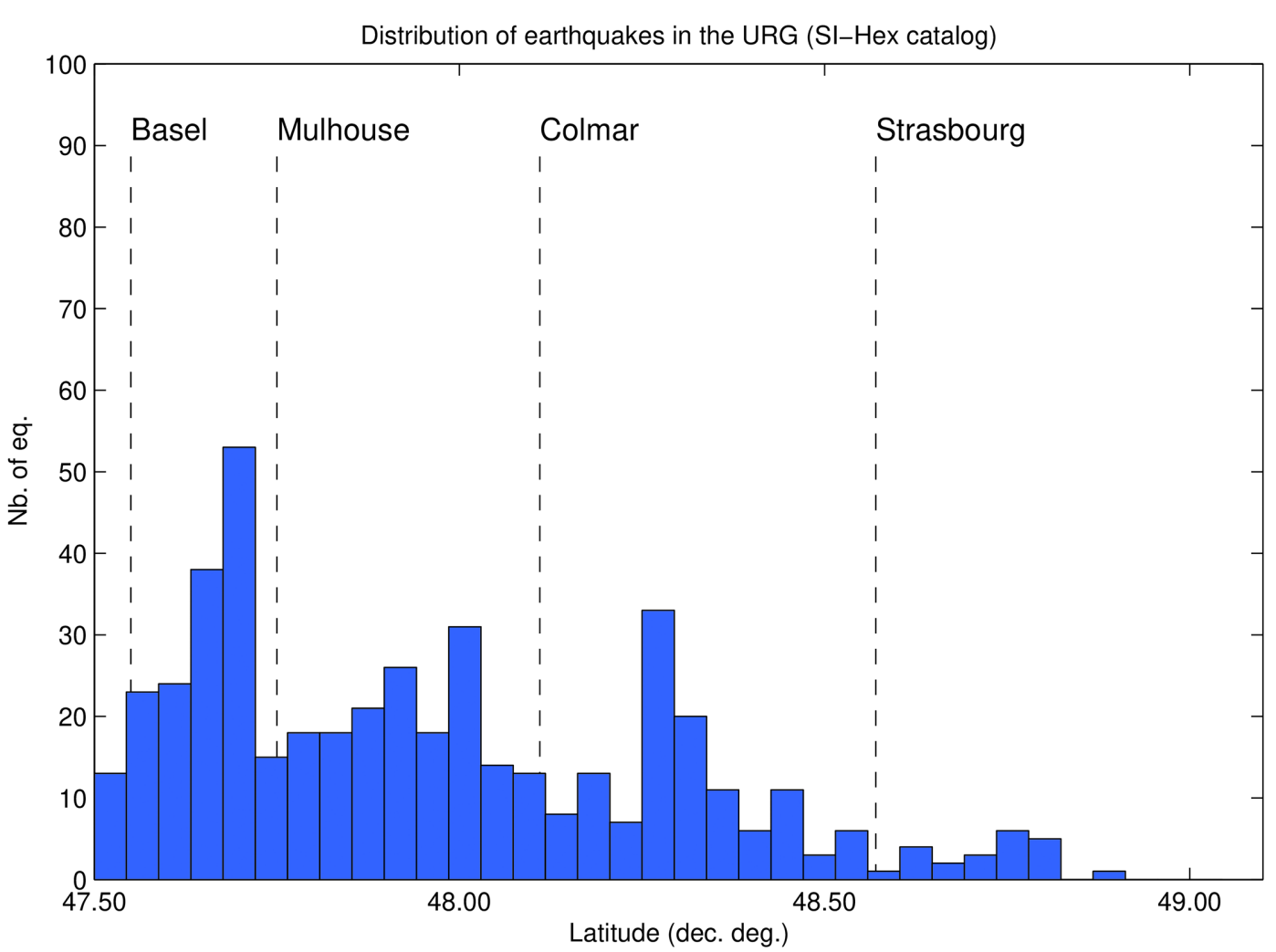

Figure 2. Distribution of earthquakes within the URG from SI-Hex catalogue (Cara et al. 2015) with $M_{\mathrm{w}} \geq 2$, occurrences as a function of latitude (in decimal degree) and localization of the main cities represented by black dotted lines.

in recent decades (1962-2009; Fig. 1b). Over the $\sim 50$-yr period of the catalogue, several earthquakes of magnitude greater than 4.0 (Table 1) have been recorded in the URG and its surrounding areas. A maximum magnitude $\left(M_{\mathrm{w}}\right)$ of 5.1 occurred in 1978 in the Swabian Jura (Germany) and is known as the Albstadt event (previously 'Ebingen'). In the Vosges (France), the maximum recorded magnitude is the $M_{\mathrm{w}} 4.9$ Rambervillers event in 2003. The instrumental seismic activity from the SI-Hex homogeneous catalogue (Cara et al. 2015) from 1962 to 2009 (Fig. 1b) shows a large concentration of low magnitude earthquakes south of a west-east trending line passing through Strasbourg $\left(48.5^{\circ} \mathrm{N}\right)$. Most of the seismicity occurs between the two main boundary faults of the graben. The earthquake density increases from Strasbourg to Basel, that is in the southernmost part of the URG (Fig. 2). This area includes the seismic sequence of Sierentz in 1980 with a main shock of $M_{\mathrm{w}} 4.1$ (Rouland et al. 1980; Maury et al. 2013) occurring just north of Basel. In the Vosges, Black Forest and Swabian Jura mountains, once again most of the seismicity is concentrated in the south (below the same EW line passing through Strasbourg). Events are less numerous than within the URG, but some significant events (e.g. the Albstadt (1978) and Rambervillers (2003) earthquakes; Table 1) have been observed in these massifs. In the southern part of the studied area some alignments of earthquakes can be proposed (Fig. 1b). The first one is orientated ENE-WSW, from Lake Constance to the Jura front, via Basel. The second one starts south of Basel toward the SW up to Lake Neuchâtel. These two alignments are roughly consistent with the directions of the Alpine and Jura front. More moderate size instrumental earthquakes $\left(M_{\mathrm{w}} \leq 4\right)$ are present on the graben shoulders than within it.

The historical seismicity shows large events, with the most important earthquake occurring near Basel in 1356 (Meyer et al. 1994; Meghraoui et al. 2001; Ferry et al. 2005; Fäh et al. 2009). The range of magnitude has been estimated between 6.0 and 6.5 (Mayer-Rosa \& Cadiot 1979; Meghraoui et al. 2001) up to 6.7-7.1 (Fäh et al. 2009) from history, seismology, archeology, palaeoseismology and engineering analysis. More recently, Shipton et al. (2016) using tectonic observations that take into account fault parameters of a dislocation model proposed a minimum value for $M_{\mathrm{w}} \max$ of 6.6 
for an earthquake as a plausible scenario in the northern URG (Riedseltz - Landau normal fault across the French and German borders; Fig. 1b). The historical seismicity also reveals a number of moderate size earthquakes $\left(M_{\mathrm{w}} \leq 5.5\right)$ within the northern part of URG and underlines the same areas of the instrumental seismicity south of the EW line passing through Strasbourg (Remiremont and Ebingen outside the URG, Basel within the URG). The less dense instrumental seismicity of the northern URG marks a north-south separation, less obvious in the historical seismicity distribution (Fig. 1b). Considering this north-south separation, the instrumental and historical seismicity patterns in the Vosges and the Black Forest are more similar to each other than to the pattern within the URG: the largest historical and instrumental event distributions in the two massifs are comparable, Remiremont (1682) and Rambervillers (2003) in the Vosges, Ebingen (1911) and Albstadt (1978) in the Swabian Jura (Fig. 1b; Table 1). More historical earthquakes are also present on the graben shoulders than within it.

Until now, geodetic studies of the URG have not given conclusive results sufficient for describing a reliable deformation field, which would clearly point out the main zones of deformation. Several results have been proposed based on GNSS campaign measurements (Rozsa et al. 2005a) and on continuous measurements either on continental scale networks by GNSS (Nocquet 2012) or on regional scale networks (Masson et al. 2019), and also by GNSS, levelling and InSAR (Knöpfler et al. 2010; Fuhrmann et al. 2013, 2015; Lutz $\&$ Brockmann 2019). In a region where the surface velocity field is characterized by low velocity $\left(<1.0 \mathrm{~mm} \mathrm{yr}^{-1}\right.$; e.g. Nocquet 2012$)$, an acquisition of data over a long period is required, estimated to be more than 6 yr according to Rosza et al. (2005a) and 8 yr according to Rabin et al. (2018). Taking advantage of the recent development of the permanent networks and the larger timespan of measurements, Knöpfler et al. (2010) and Fuhrmann et al. (2013, 2015) propose dense GNSS velocity fields over the whole URG region, by analysing an original data set coming from the GURN network (Fig. 3). The GURN network is a transnational cooperation between the Ecole et Observatoire des Sciences de la Terre (EOST, CNRS and University of Strasbourg) and the Geodetic Institute of Karlsruhe University (GIK, Germany) which began in 2008 (Knöpfler et al. 2010). The dense GNSS network within the URG aims to detect small ground displacements and provides a 3-D velocity field of the surface.

\section{PROCESSING OF GNSS DATA}

The data used in this study have been acquired by 81 permanent stations of the GURN network (Fig. 2). The observations cover the time span from 2002 to 2018 January. The sites are mainly located in the URG, Vosges, Black Forest, Jura and Swabian Jura massifs. The average distance between two sites is $\sim 40-60 \mathrm{~km}$. The sampling rate was $30 \mathrm{~s}$ for all the stations of the network.

\subsection{Data processing}

The GNSS data were processed using the GPS Analysis at MIT/Global Kalman filter (GAMIT/GLOBK) processing chain (Herring et al. 2018a). It provides a daily solution of the GURN network from the RINEX (Receiver INdependent EXchange) files and the IGS (International GNSS Service) final orbit products. The GAMIT/GLOBK processing is in two steps. First, a daily loosely constrained solution (no constraint on the GURN network coordinates and only $5 \mathrm{~cm}$ on reference network coordinates) with a covariance matrix is provided by GAMIT (Herring et al. 2018b). Second, the daily solutions are combined in GLOBK with a Kalman filter to obtain the position time-series, the average coordinates and velocities of the stations (Herring et al. 2015), with a referencing in ITRF2014 (Altamimi et al. 2016).

In order to obtain the lowest possible uncertainties on the velocity estimates, we conduct two corrections on the position time-series calculated from GLOBK. First, we remove the detected outliers from the position time-series of a station. We exclude any points which are approximately three times the standard deviation of the values in the position time-series of vertical displacements, from the mean value for each component after removing the trend. Second, we correct the offsets in the position time-series as shown in Fig. 4. These offsets are generally due to antenna or equipment changes, although occasionally no obvious cause is associated with them. The offset correction is in two steps, first the processing of the GURN network with a decimation every $5 \mathrm{~d}$ is carried out (left-hand panels of the Fig. 4). A 'linear single-phase single-slope sinusoidal' model of the position time-series is estimated using the least-squares method. The model is associated with the following $f$ function defined by:

$$
\begin{aligned}
f(t)= & a \cdot \cos (2 \pi v t)+b \cdot \sin (2 \pi v t)+c \cdot t+d \\
& +\sum_{i=1}^{N} e_{i} \cdot \mathcal{H}\left(t-t_{i}\right)
\end{aligned}
$$

In eq. (1), $t$ is the time variable, $v$ is the frequency which dominates the time-series spectrum (chosen between 0.8 and $1.2 \mathrm{yr}^{-1}$ ), $N$ is the number of offsets detected in the time-series, $e_{i}$ is the amplitude of the offset detected at $t_{i}, H$ is the Heaviside function, and $a, b, c, d$ are the parameters of the model.

The offset occurrences are manually pointed out, and the model is re-estimated for each new section of the position time-series delimited by these occurrences. For example, if a position timeseries includes two offsets, then three models will be estimated. Then, the offset values correspond to the distance between two consecutive models. Second, all the calculated offset values are considered for a second GAMIT/GLOBK processing. The corrected time-series are then obtained (right-hand panels of Fig. 4).

Finally, the position time-series from GNSS data are known to be affected by time-correlated noise in addition to time-uncorrelated noise (Langbein \& Johnson 1997; Langbein 2012). These noises can be represented by power-law forms as a function of $1 / f^{n}$ ( $f$ : frequency of the signal) in the frequency domain. If $n=0$, it is white noise (time-uncorrelated); if $n=1$ it is flicker noise (highfrequency time-correlated); and if $n=2$ it is random walk (lowfrequency time-correlated) (Langbein 2012; Dmitrieva et al. 2016). Neglecting the temporally correlated noise leads to an underestimation of the uncertainty of the velocity (Langbein 2012). So, from the corrected position time-series, the uncertainties of the velocities are estimated using the 'Create and Analyze Time Series' software (CATS; Williams 2008). The CATS software fits a multiparameter model using a least-squares method and jointly analyses the residuals by maximum likelihood estimation. We assume that the position time-series are affected by a combination of white and flicker noises, and by random walk. These amplitudes, estimated by the CATS software, are used in an empirical model given by Mao et al. (1999), which gives the uncertainty of the velocity for each component according to eq. (2):

$\sigma=\sqrt{\frac{12 \sigma_{w}^{2}}{g T^{3}}+\frac{a \sigma_{f}^{2}}{g^{b} T^{2}}+\frac{\sigma_{r w}^{2}}{T}}$ 


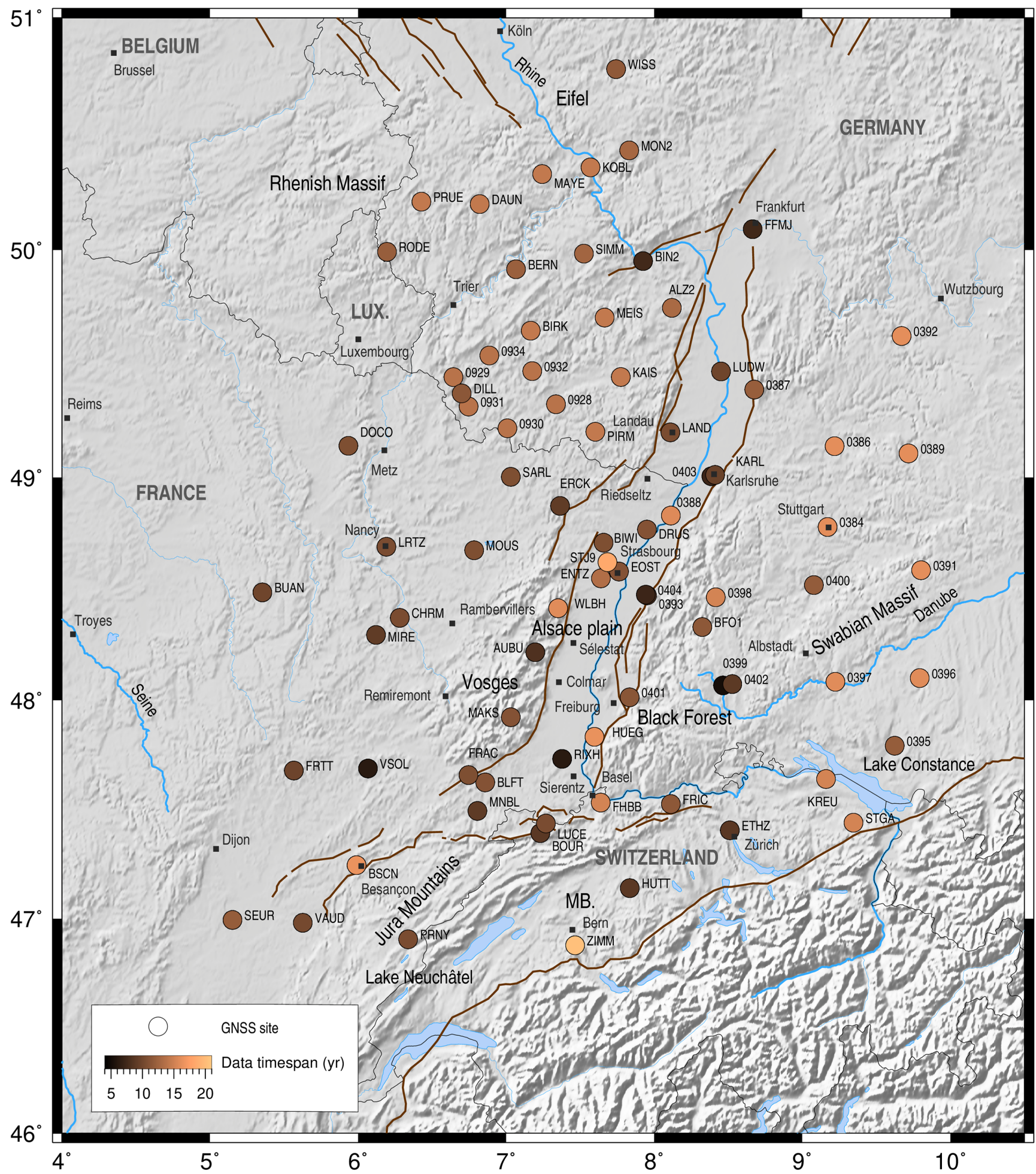

Figure 3. The GURN network, sites represented by the amount of observations. DEM: GTOPO30.

In eq. (2), $\sigma$ is the uncertainty on the velocity, $\sigma_{\mathrm{w}}$ and $\sigma_{\mathrm{f}}$ are the magnitudes of white and flicker noises, $\sigma_{\mathrm{rw}}$ is the magnitude of random walk, $g$ is the number of measurements per year, $T$ is the total time span in years and $a$ and $\mathrm{b}$ are empirical constants. According to eq. (2), increasing the volume of data leads to reduce the uncertainties on the velocities.

\subsection{Velocity field reference frame}

Using the corrected position time-series of the selected stations, we compute the velocities in the ITRF2014 (Altamimi et al. 2016). There are 14 reference stations distributed around the GURN network in France, Germany, Netherlands, Sweden, Poland, Austria, Switzerland, Italy and Spain (see Table 2). These reference sites 

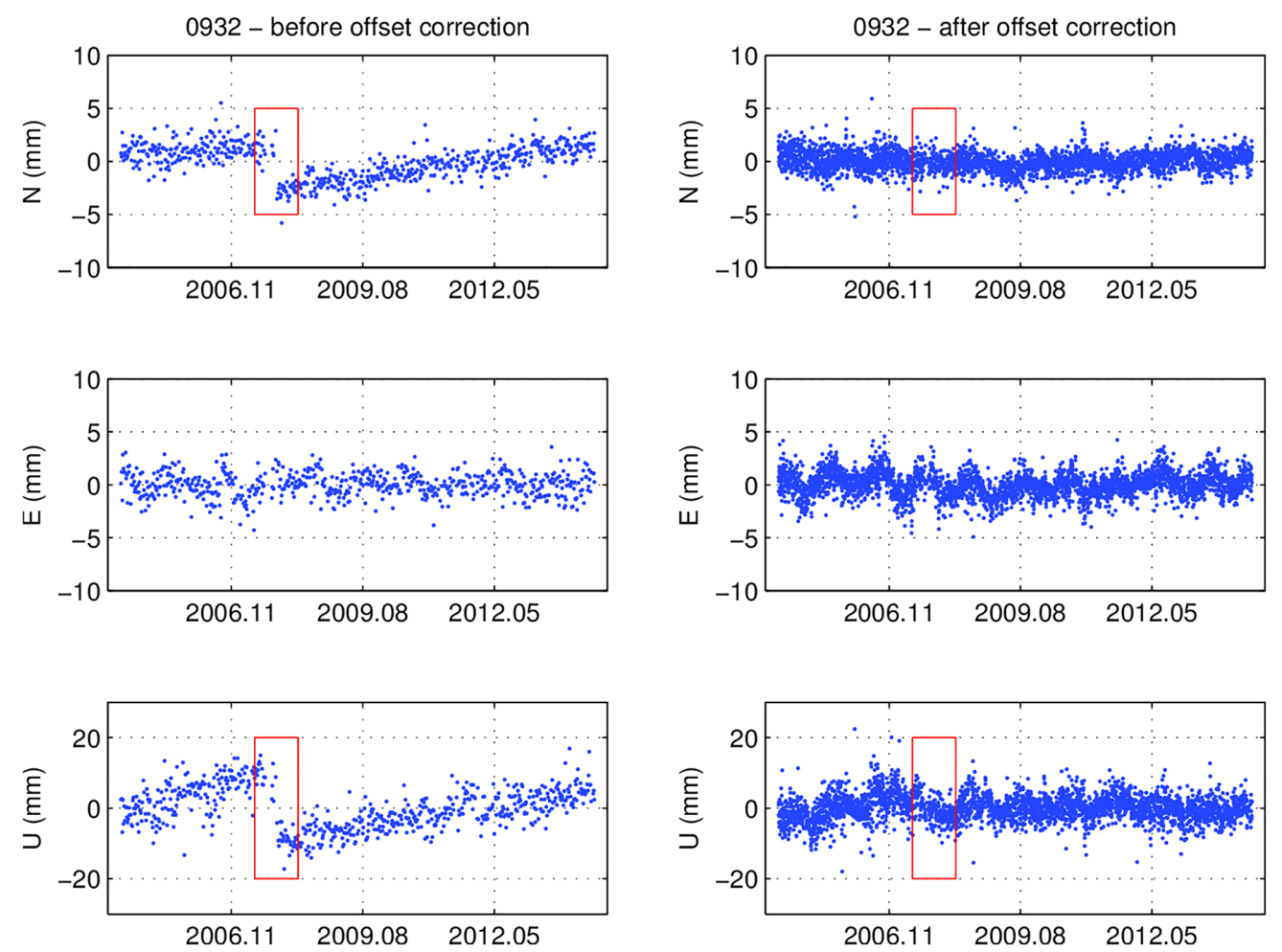

Figure 4. Position time-series 0932 site for north, east and vertical components (mm) before and after offset correction.

Table 2. Reference sites: site, longitude $\left({ }^{\circ}\right)$, latitude $\left({ }^{\circ}\right)$, observation duration (yr) and network.

\begin{tabular}{lcccll}
\hline Site & $\begin{array}{c}\text { Lon. } \\
\left({ }^{\circ}\right)\end{array}$ & $\begin{array}{c}\text { Lat. } \\
\left({ }^{\circ}\right)\end{array}$ & $\begin{array}{c}\text { Obs. } \\
(\mathrm{yr})\end{array}$ & \multicolumn{1}{c}{ Country } & Network \\
\hline GENO & 8.9212 & 44.4194 & 12.0 & Italy & IGS \\
GRAZ & 15.4935 & 47.0671 & 15.0 & Austria & IGS \\
JOZE & 21.0315 & 52.0973 & 14.4 & Poland & IGS \\
MATE & 16.7045 & 40.6491 & 16.0 & Italy & IGS \\
MLVL & 2.5873 & 48.8411 & 15.0 & France & EUREF \\
NOT1 & 14.9898 & 36.8759 & 16.0 & Italy & IGS \\
ONSA & 11.9255 & 57.3953 & 16.0 & Sweden & IGS \\
POTS & 13.0661 & 52.3793 & 15.0 & Germany & IGS \\
SJDV & 4.6766 & 45.8791 & 13.4 & France & EUREF \\
SOPH & 7.0541 & 43.6114 & 13.4 & France & RENAG \\
VILL & -3.9520 & 40.4436 & 14.4 & Spain & IGS \\
WSRT & 6.6045 & 52.9146 & 16.0 & Netherlands & IGS \\
WTZR & 12.8789 & 49.1442 & 16.0 & Germany & IGS \\
ZIMM & 7.4653 & 46.8771 & 16.0 & Switzerland & IGS \\
\hline
\end{tabular}

are used to estimate a constraint velocity field with respect to the Eurasia reference frame. Then we estimate the velocity field within the Eurasian reference frame. We compute a local Euler pole from the velocities of the GURN network presented in Fig. 3 by following an approach of minimization of the residuals. The Euler pole of Altamimi et al. (2017) is used as a first approximation $\left(\right.$ Lat $=55.070 \pm 0.004^{\circ} \mathrm{N}$, Lon $=-99.094 \pm 0.007^{\circ} \mathrm{E}, \omega=$ $\left.0.261 \pm 0.001^{\circ} \mathrm{Ma}^{-1}\right)$, the coordinates of the local Euler pole are: Lat $=55.091^{\circ} \mathrm{N}$, Lon $=-99.138^{\circ} \mathrm{E}, \omega=0.261^{\circ} \mathrm{Ma}^{-1}$ ). The uncertainties of the geographic coordinates and angular velocity are propagated to the local Euler pole solution.

The vertical velocity field has been obtained after removing the mean value from the velocities of the GURN network presented in Fig. $3\left(-0.29 \mathrm{~mm} \mathrm{yr}^{-1}\right)$. A correction by a mean value of vertical velocities is adequate for applying a uniform correction because the GURN network is not affected by long-wavelength phenomenon depending on latitude. The GURN network is also unaffected by the glacial isostatic adjustment (GIA) as shown by the ICE_6 G model (Peltier et al. 2015), which is computed from GNSS data and refined by GRACE data. These studies have shown that GIA is insignificant south of $\sim 53^{\circ} \mathrm{N}$ (Peltier et al. 2015; Bogusz et al. 2019) when the highest latitude of a GURN network site is $50.781^{\circ} \mathrm{N}$.

\subsection{Strain rate tensor}

To compute the strain rate tensor, we used the STIB method (Strain Tensor from Inversion of Baselines, Masson et al. 2014), which 
exploits redundancies in our GPS measurements by inverting the velocity differences on baselines between all station couples across the entire network to produce a regional strain map. The method is particularly suited for continuous deformation or for low tectonic activity regions, where the ground displacements are below the displacement accuracy (Masson et al. 2014). We use a model of $6^{\circ}$ longitude and $5^{\circ}$ latitude grid with a regular spacing of $0.3^{\circ}$. The model is computed with a constant a priori value for the diagonal covariance matrix of $5 \mathrm{e}-09 \mathrm{yr}^{-1}$.

\section{DESCRIPTION OF THE VELOCITY FIE L D}

Fig. 5 presents both the (a) horizontal and (b) vertical velocity fields with 95 per cent confidence uncertainties with respect to the fixed Eurasian reference described above. The velocity values are given in Table 3. Regarding the horizontal velocity field, and as observed by previous studies (e.g. Nocquet 2012; Masson et al. 2019), a striking observation is the amplitude of the velocities which are all smaller than the upper bound detected of $0.6 \mathrm{~mm} \mathrm{yr}^{-1}$ (Nocquet 2012), $0.37 \pm 0.30 \mathrm{~mm} \mathrm{yr}^{-1}$ being the mean velocity for the entire GURN network. To avoid inconsistencies between neighbouring sites, we conduct an analysis by group of stations which shows coherent spatial movements. The horizontal velocity field shows heterogeneous velocity directions with low velocity amplitudes, except for the southern region, area A in Fig. 5(a), between the Alps and the Jura front where a slight but consistent northward movement is observed. The mean uncertainty on the horizontal velocity $\left( \pm 0.30 \mathrm{~mm} \mathrm{yr}^{-1}\right)$ is lower than the mean uncertainties from previous studies, namely $\pm 0.35 \mathrm{~mm} \mathrm{yr}^{-1}$ for Fuhrmann et al. (2013) or $\pm 0.4 \mathrm{~mm} \mathrm{yr}^{-1}$ for Fuhrmann et al. (2015), due to longer time-series with the duration displayed in Table $3(\sim 12 \mathrm{yr}$ for this study in comparison of $\sim 5 \mathrm{yr}$ from Fuhrmann et al. 2013, 2015) and due to our processing strategy to correct the offsets in the position time-series.

\subsection{Horizontal velocities}

As mentioned above, south of the Rhine Graben, in the Jura Mountains, the Molasse Basin (MB. on Figs 5a and b), and along the Alpine front, consistent northward velocities of $0.49 \pm 0.33 \mathrm{~mm} \mathrm{yr}^{-1}$ are observed from ZIMM to STGA, including HUTT and ETHZ (consistent with a northward velocity of $0.34 \pm 0.06 \mathrm{~mm} \mathrm{yr}^{-1}$ in a France-centred reference frame from Masson et al. 2019). Going north, velocities decrease rapidly across the Jura and the Jura front. BOUR, LUCE, FHBB and FRIC, close to the Jura front, have a northward velocity ranging from 0.10 to $0.46 \mathrm{~mm} \mathrm{yr}^{-1}$. These results are consistent to the east with the study of Serpelloni et al. (2016), which shows shortening in the Eastern Alps (1.0 $\mathrm{mm} \mathrm{yr}^{-1}$ of northward movement in the Carnic Alps and $0.7 \mathrm{~mm} \mathrm{yr}^{-1}$ north-westward movement in the Dolomites) and those obtained in the same area by Rabin et al. (2018).

Only very low velocities are obtained, mostly below $0.2 \mathrm{~mm} \mathrm{yr}^{-1}$, from the French BSCN and FRTT sites. These are located close to Besançon and Dijon in the south-west of the GURN network; and the German 0392 site is located close to Wutzbourg in the northeast, including the central part of the URG from Sélestat in the south to Karlsruhe in the north (KARL) via Strasbourg (STJ9, EOST and ENTZ). This result confirms the lack of significant current relative variations from one site to neighbouring sites in the central part of the URG. The low amplitudes of our estimated velocities compared to previous studies result from our longer duration of measurement. A similar observation has been shown in the New Madrid Seismic Zone (NMSZ) study (Calais \& Stein 2009) where the velocity and uncertainty amplitudes decrease with the amount of observations (1.4 $\mathrm{mm} \mathrm{yr}^{-1}$ for studies conducted in 2002-2003, $0.7 \mathrm{~mm} \mathrm{yr}^{-1}$ for 2006 and until $0.2 \mathrm{~mm} \mathrm{yr}^{-1}$ in 2009).

\subsection{Vertical velocities}

The uncertainties associated with the vertical velocities are, as expected, larger than the horizontal velocities (a mean value of $0.52 \mathrm{~mm} \mathrm{yr}^{-1}$ ). However, consistent patterns are observable in Fig. 5(b) within the URG, on its shoulders (Vosges Massif and Black Forest Massif), in the northwest (Rhenish Massif) and in the south (between the Alpine and Jura fronts).

Along the eastern shoulder of the URG (from Karlsruhe to Fribourg) and south of the Jura Massif and Swabian Massif (from ZIMM to 0396), a smaller and discontinuous signal is visible of $0.16 \pm 0.43 \mathrm{~mm} \mathrm{yr}^{-1}$. In the URG, from Frankfurt to north of Basel, significant subsidence is observed. Subsidence is also observed west of the URG toward the Bresse Graben (Dijon). Some previous levelling studies confirm our results. A subsidence of $-0.25 \pm 0.02 \mathrm{~mm} \mathrm{yr}^{-1}$ has been proposed by Rozsa et al. (2005b) for the region of Freiburg using levelling, which is consistent with a small subsidence obtained with the HUEG (the closest site, $-0.09 \pm 0.32 \mathrm{~mm} \mathrm{yr}^{-1}$ ). In the southern URG, Ziegler (1992) proposed extremely small vertical rates (levelling data from DKG-ARH (1979)), about -0.1 to $0.2 \mathrm{~mm} \mathrm{yr}^{-1}$ measured between $1922-39$ and 1952-62. Our processed GNSS data from the HUEG and FHBB sites in this area present consistent velocities of $-0.09 \pm 0.32$ and $0.01 \pm 0.33 \mathrm{~mm} \mathrm{yr}^{-1}$, respectively. In the variations of the vertical velocities, we exclude a significant contribution of the GIA, which has a wavelength variation far larger than the scale of our study. In the URG we cannot exclude the possibility of an anthropogenic origin for the subsidence. For example, LAND undergoes a subsidence of $-1.47 \pm 0.43 \mathrm{~mm} \mathrm{yr}^{-1}$, which is likely due to anthropogenic activities like groundwater pumping, oil extraction, or production of geothermal energy (Fuhrmann et al. 2015; Heimlich et al. 2015).

In the north-western part of the network, we observe a small but spatially homogeneous signal. An uplift in the Rhenish Massif, and more specifically in the Eifel volcanic field (area B in Fig. 5b) is highlighted by the upward velocities of five stations (DAUN, MAYE, KOBL MON2 and WISS) and a mean value of $1.17 \pm 0.43 \mathrm{~mm} \mathrm{yr}^{-1}$. Indeed, the Rhenish Massif underwent an uplift since the late Miocene (Ziegler 1992) with an average velocity of $0.06 \mathrm{~mm} \mathrm{yr}^{-1}$ estimated from in situ stress determination by overcoming technique (Illies \& Greiner 1979). Between 700 and 10.8 ka BP, the area underwent an uplift which has been quantified by Meyer and Stets (1998) to $250 \mathrm{~m}$ corresponding to a mean velocity of $\sim 0.35 \mathrm{~mm} \mathrm{yr}^{-1}$. In the Eifel volcanic field, west of the Rhine, about 300 small eruptions have occurred in the past (Schmincke et al. 1983). Using precision levelling, Ziegler (1992) has proposed an upward velocity of the Rhenish Massif of $0.4-0.6 \mathrm{~mm} \mathrm{yr}^{-1}$, with a maximum value of $1.0 \mathrm{~mm} \mathrm{yr}^{-1}$ in the Eifel area (Area B in Fig. 5b) measured between 1934-57 and 1968-73.

Tomographic studies have shown a low-velocity zone in the lithosphere below the Eifel area (Ritter et al. 2001). The lithosphereasthenosphere boundary is about $60 \pm 5 \mathrm{~km}$ deep in the URG, but it is only $41 \pm 5 \mathrm{~km}$ in the Eifel volcanic province. Seiberlich et al. (2013) suggest an uplift of the mantle material which erodes the lithosphere lower boundary in the Eifel area. These deep and 

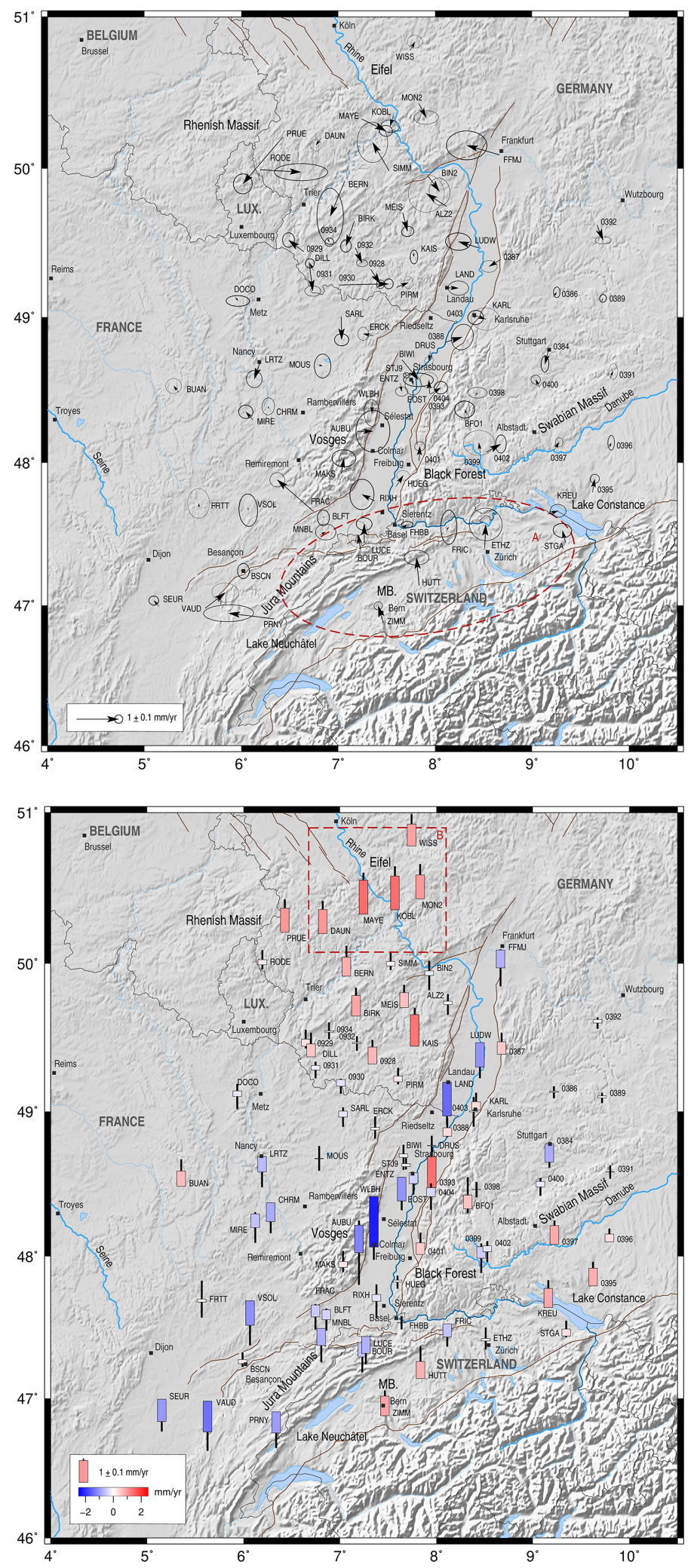

Figure 5 . (a) Horizontal velocity field, area A represented by a dotted red ellipse. (b) Vertical velocity field, the vertical velocities are symbolized as coloured rectangles with the uncertainty as a black line at the extremity, the location of the site is at the bottom of the rectangle (if the black line is pointing down, there is subsidence). Area B is represented by a dotted red rectangle. In both figures, major faults represented by brown lines. MB: Molassic Basin. DEM: GTOPO30. 
Table 3. GURN sites: site, longitude $\left({ }^{\circ}\right)$, latitude $\left({ }^{\circ}\right)$, east and north velocities $\left(\mathrm{mm} \mathrm{yr}^{-1}\right)$ and their uncertainties $\left(\mathrm{mm} \mathrm{yr}^{-1}\right)$, correlation $\left(\mathrm{mm} \mathrm{yr}^{-1}\right)$, vertical velocities $\left(\mathrm{mm} \mathrm{yr}^{-1}\right)$ and their uncertainties $\left(\mathrm{mm} \mathrm{yr}^{-1}\right)$, observation duration $(\mathrm{yr})$ and network.

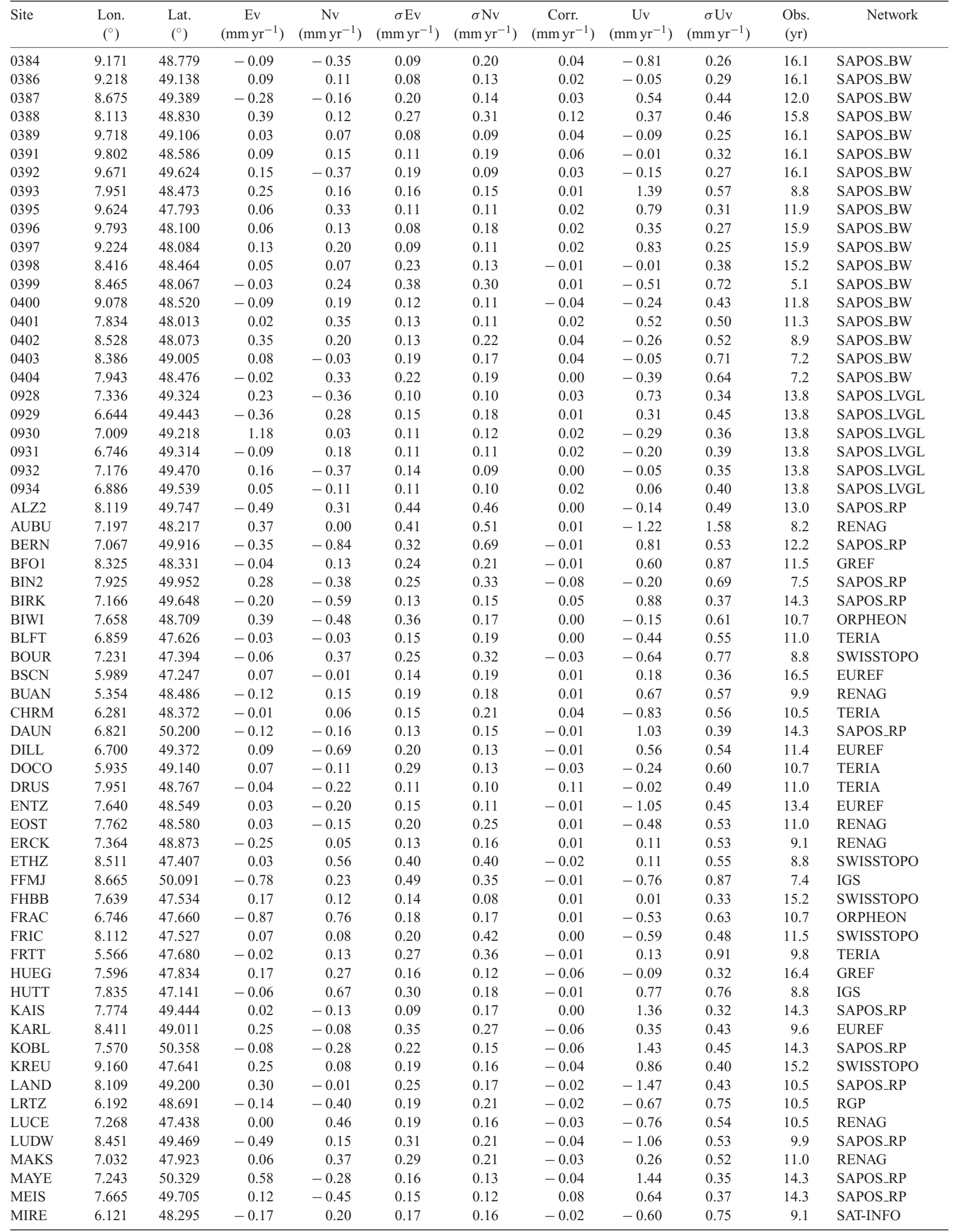


Table 3. Continued

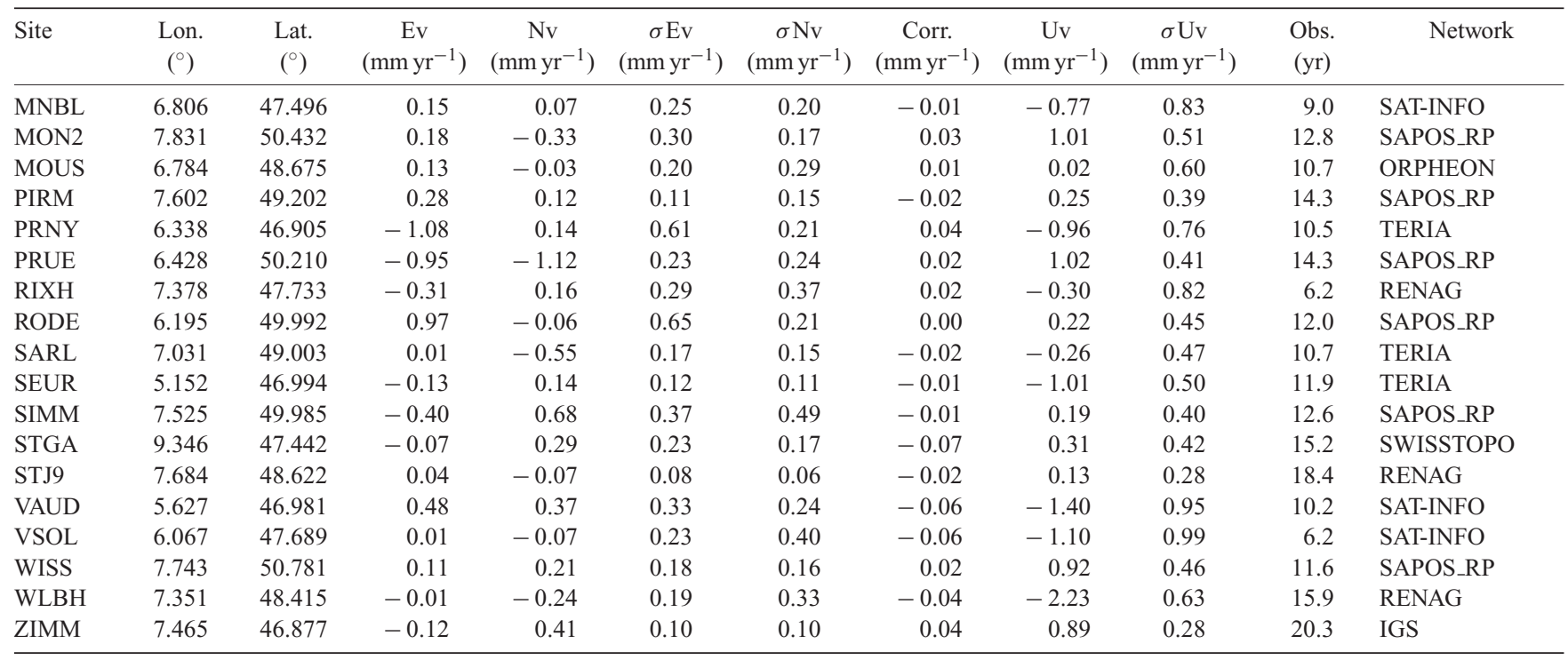

complex processes could be responsible for the observed uplift in the Eifel area. In addition, low-frequency earthquakes have been detected in the Eifel area between 2013 and 2018 (Hensch et al. 2019). The earthquakes are spatially distributed in four clusters between $\sim 10$ and $\sim 40 \mathrm{~km}$ depth. The low-frequency earthquakes and gas emissions indicate an active magmatic system with magma flow migration. The magmatic recharging would result in an upward flow migration located under the Laacher See Volcano (Hensch et al. 2019). The closest site (MAYE) shows the maximal vertical velocity of $1.44 \pm 0.35 \mathrm{~mm} \mathrm{yr}^{-1}$.

\subsection{Strain rate tensor}

The strain rate tensor is represented in Fig. 6. The major observation is a NNW-SSE shortening between the Alpine front and the Jura Mountains of $7 \mathrm{e}-09 \mathrm{yr}^{-1}$ (area A in Fig. 6; corresponding to $0.3 \mathrm{~mm} \mathrm{yr}^{-1}$ shortening for $50 \mathrm{~km}$ ). Previous studies have published some results for this area: Tesauro et al. (2006) proposed an NW-SE compression of $7 \pm 2 \mathrm{e}-09 \mathrm{yr}^{-1}$ from GNSS data acquired from 1996 to 2004 and an NW-SE compression of $10 \mathrm{e}-09 \mathrm{yr}^{-1}$ from inversion of seismic focal mechanisms; Rabin et al. (2018) proposed a smaller NW-SE shortening of $2.86 \pm 0.2 \mathrm{e}-09 \mathrm{yr}^{-1}$ from GNSS data. West of this area, we observe a strike-slip regime within the Jura Massif surrounded by ENE-WSW compression along the western end of the Jura. Going north, there is no area where clear consistent strain is observed. For example, no clear extension or strike-slip signal is observed in the URG as expected from long-term topography and focal mechanisms earthquakes (Bonjer 1997; Maury et al. 2013).

\section{DISCUSSION}

It is difficult to link horizontal deformation with instrumental and historical seismicity to explain possible neotectonics activity. Especially in the case where the horizontal deformation field is calculated with small velocities which display large uncertainties for several stations, or with an incomplete catalogue of historical earthquakes.

An initial surprising observation is that the high seismicity zone south of the URG corresponds to the highest GNSS velocities of the region (Fig. 5a). This is the region along the two alignments described in Section 2, the area of the Basel earthquake, that is parallel to the Alpine and Jura fronts (Fig. 1b). Here, the horizontal velocity field appears coherent with a northward movement observed at several neighbouring stations $\left(0.49 \pm 0.33 \mathrm{~mm} \mathrm{yr}^{-1}\right)$ compared to others with small velocities observed $\left(0.16 \pm 0.29 \mathrm{~mm} \mathrm{yr}^{-1}\right)$ at $\sim 50 \mathrm{~km}$ northward, which corresponds to a deformation of $\sim 6.6 \mathrm{e}-$ $09 \mathrm{yr}^{-1}$. The GNSS observations allow us to infer that the relatively dense seismicity south of the URG and north of the Alpine front in Switzerland is probably related to the large-scale tectonics of the Alps. In the southernmost part of the URG, seismicity takes place where geodetic deformation is observed. Conversely, the lack of current geodetic deformation observed across the URG area along an SW-NE axis (from the Vosges to the Black Forest in Fig. 5a) and from the region extending from Strasbourg to Karlsruhe in particular, suggests that both historical and instrumental events cannot be explained by significant measurable current tectonic movements observed from geodetic data. Nevertheless, the absence of geodetic measurements does not imply the absence of deformation. Indeed, Shipton et al. (2016) have identified an active fault in the central part of the URG.

Several examples worldwide show that moderate to large earthquakes together with a regular microseismicty can occur in regions where no evidence of deformation is measurable by GNSS. The most famous examples are the NMSZ in Central North America (1811-1812) (Johnston \& Schweig 1996; Calais \& Stein 2009) and the Tennant Creek earthquakes in Australia (1988) (Choy \& Bowman 1990).

Similar to the NWSZ, the geodetic results presented in this paper confirm that the stable continental region of the URG undergoes little or no deformation. Large faults bounding the URG have the required dimensions to produce large-scale earthquakes of a magnitude up to 7.0. However, even if a very slow tectonic loading remains a possible explanation for the origin of the seismicity in the URG region, the analysis of the seismicity in light of the notion of a seismic cycle remains complex, due to the potential recurrence time being too long and the historical catalogue being too short. More investigation into palaoseismological data appear necessary to enlarge the fault slip database over the whole region in order to estimate the balance between tectonic strain accumulation and release by large earthquakes. The southern part of the URG is the only area with consistent observable deformation; the most intense 


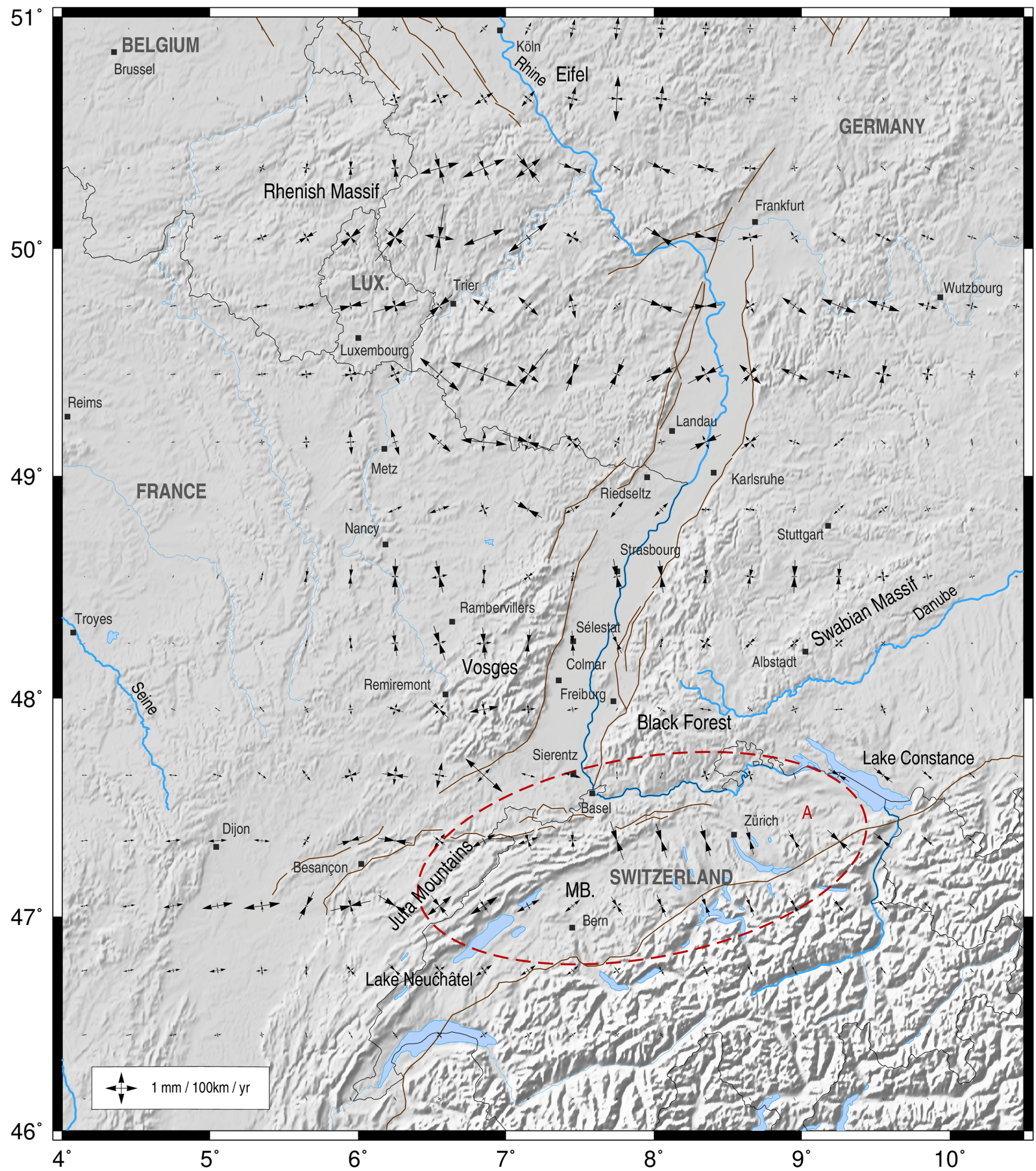

Figure 6. Strain rate tensor of deformation, area A represented by a dotted red ellipse. DEM: GTOPO30.

seismicity of the region therefore suggests the possible role of the buildup and release of tectonic stresses on the fault reactivation associated with the Rhine Graben, the Jura front and the Alpine Arc. However, the other arguments related to local and/or transient stress changes and proposed for the occurrence of seismicity in the case of NMSZ can also be made for all of the URG, both north and south. Following Wu \& Johnston (2000), the effect of the melt of the ice cap from the last glaciation period is too negligible in the area of the URG to produce horizontal displacement gradients and strain. However, other processes are susceptible to inducing local stress changes in the upper crust, such as the response to erosional unloading of the Vosges and Black Forest (Meyer et al. 2010; Ackerer et al. 2016), together with its lateral gradient from the elevated regions to the Alsace plain. This plain also sustains seasonal change 
of water storage, particularly in the first $5 \mathrm{~km}$ filled with saturated levels of gravels and unconsolidated sediments. Finally, Audin et al. (2002) have proposed an explanation of the seismicity in the Vosges by the circulation of fluid migration at narrow depth.

Therefore, in an intraplate region such as the URG region, the estimate of hazard is difficult but crucial to access, given the high seismic risk of an urbanized and industrialized basin that includes a nuclear power plant and various chemical industries. The estimate cannot be deduced merely from probabilistic seismic hazard based on frequency-magnitude statistics. The surface velocity field and strain rate tensor help improve the constraining of the relative roles of tectonic loading and other potential origins of the seismicity. Except for the southern part of the URG where surface deformation reveals strain accumulation, our results suggest that many nontectonic natural processes must be investigated to understand the seismic activity of the whole URG region. The seismic response of pre-existing inherited faults to local and/or transient loading is particularly important in a region where industrial activity such as geothermal plants might be involved in the triggering of seismic sequences near highly populated zones, as was the case for the recent sequence in Strasbourg (2019 November).

\section{CONCLUSION}

From a new GPS velocity field of the URG and its surroundings, we characterize the region's deformation and link it with the seismicity. The study is based on a dense GNSS network called GURN, a network spread across the whole URG and areas around the graben, with sites having up to $16 \mathrm{yr}$ of observations. The corrections made during the processing bring a reliable velocity field with low uncertainties, which lead to the detection of small crustal displacements. The centre of the URG is not affected by any quantifiable deformation while a northward coherent movement of $0.49 \pm 0.33 \mathrm{~mm} \mathrm{yr}^{-1}$ is observable in the south of the URG. This probably corresponds to the Jura front shortening $\left(7 \mathrm{e}-09 \mathrm{yr}^{-1}\right)$ and could be the cause of the seismic activity in the area. The analysis of the vertical component shows an uplift of $1.17 \pm 0.43 \mathrm{~mm} \mathrm{yr}^{-1}$ in the north of the URG. Perhaps this is due to the presence of past volcanic activity in the area (the last Eifel province eruption of the Laacher See volcano was $11000 \mathrm{yr}$ ago), and due to deep low-frequency earthquakes detected between 2013 and 2018.

\section{ACKNOWLEDGEMENTS}

This study has been finalized during the $\mathrm{PhD}$ of Eric HENRION co-funded by the companies Électricité de Strasbourg (ÉS) and Storengy. The authors are thankful to Sophie Lambotte for the access to an updated instrumental seismicity database. We are indebted to late Jean Vogt and Julien Frechet for the access to the historical seismicity data. The GURN data are provided by several scientific institutions managing networks: SAPOS from Germany, private (ORPHEON) and public (RENAG-RESIF, RGP) networks from France, and Swisstopo from Switzerland. The geodetic data can be used on request by agreement of all partners. We are thankful to Maximilien Lehujeur for his code to correct the offsets in the GNSS position time-series. We would like to thank the editor and peer reviewers for their valuable comments and suggestions that helped in the improvement of earlier versions of the manuscript.

\section{REFERENCES}

Ackerer, J., Chabaux, F., Van der Woerd, J., Viville, D., Pelt, E., Kali, E. \& Négrel, P., 2016. Regolith evolution on the millennial timescale from combined U-Th-Ra isotopes and in situ cosmogenic 10Be analysis in a weathering profile (Strengbach catchment, France), Earth planet. Sci. Lett., 453, 33-43.

Altamimi, Z., Rebischung, P., Métivier, L. \& Collilieux, X., 2016. ITRF2014: a new release of the International Terrestrial Reference Frame modeling nonlinear station motions, J. geophys. Res.: Solid Earth, 121(8), 61096131.

Altamimi, Z., Métivier, L., Rebischung, P., Rouby, H. \& Collilieux, X., 2017. ITRF2014 plate motion model, Geophys. J. Int., 209(3), 1906-1912.

Audin, L., Avouac, J.P., Flouzat, M. \& Plantet, J.L., 2002. Fluid-driven seismicity in a stable tectonic context: The Remiremont fault zone, Vosges, France, Geophys. Res. Lett., 29(6), 13-1.

Bogusz, J., Klos, A. \& Pokonieczny, K., 2019. Optimal strategy of a GPS position time series analysis for post-glacial rebound investigation in Europe, Remote Sens., 11(10), 1209,.

Bonjer, K.P., 1997. Seismicity pattern and style of seismic faulting at the eastern borderfault of the southern Rhine Graben, Tectonophysics, 275 (1-3), 41-69.

Calais, E. \& Stein, S., 2009. Time-variable deformation in the New Madrid seismic zone, Science, 323(5920), 1442-1442.

Cara, M., Cansi, Y., Schlupp, A., Arroucau, P., Béthoux, N., Beucler, E. \& Delouis, B., 2015. SI-Hex: a new catalogue of instrumental seismicity for metropolitan France, Bull. Soc. géol. France, 186(1), 3-19.

Choy, G.L. \& Bowman, J.R., 1990. Rupture process of a multiple main shock sequence: analysis of teleseismic, local and field observations of the Tennant Creek, Australia, earthquakes of January 22, 1988, J. geophys. Res., 95, 6867-6882.

Delouis, B., Haessler, H., Cisternas, A. \& Rivera, L., 1993. Stress tensor determination in France and neighbouring regions, Tectonophysics, 221, 413-438.

DKG-ARH, 1979. On the map of height changes in the Federal Republic of Germany Status 1975, scale 1:1,000,000, Allg. Vermessungs Nachr, 86(10), 362-364.

Dmitrieva, K., Segall, P. \& Bradley, A.M., 2016. Effects of linear trends on estimation of noise in GNSS position time series, Geophys. J. Int., 208, 281-288.

Fäh, D., Gisler, M., Jaggi, B., Kästi, P., Lutz, T., Masciadri, V. \& Tauber, J., 2009. The 1356 Basel earthquake: an interdisciplinary revision, Geophys. J. Int., 178(1), 351-374.

Ferry, M., Meghraoui, M., Delouis, B. \& Giardini, D., 2005. Evidence for Holocene palaeoseismicity along the Basel - Reinach active normal fault (Switzerland): a seismic source for the 1356 earthquake in the Upper Rhine Graben, Geophys. J. Int., 160(2), 554-572.

Furhmann, T., Heck, B., Knöpfler, A., Masson, F., Mayer, M., Ulrich, P., Westerhaus, M. \& Zippelt, K., 2013. Recent surface displacements in the Upper Rhine Graben-preliminary results from geodetic networks, Tectonophysics, 602, 300-315.

Furhmann, T., Caro Cuenca, M., Knöpfler, A., van Leijen, F.J., Mayer, M., Westerhaus, M., Hanssen, R.F. \& Heck, B., 2015. Estimation of small surface displacements in the Upper Rhine Graben area from a combined analysis of PS-InSAR, levelling and GNSS data, Geophys. J. Int., 203, 614-631.

Heidbach, O., Rajabi, M., Reiter, K. \& Ziegler, M., 2016. World Stress Map 2016, GFZ Data Service, doi:10.5880/WSM.2016.002.

Heimlich, C., Gourmelen, N., Masson, F., Schmittbuhl, J., Kim, S.W. \& Azzola, J., 2015. Uplift around the geothermal power plant of Landau (Germany) as observed by InSAR monitoring, Geotherm. Energy, 3(1), 2.

Hensch, M., Dahm, T., Ritter, J., Heimann, S., Schmidt, B., Stange, S. \& Lehmann, K., 2019. Deep low-frequency earthquakes reveal ongoing magmatic recharge beneath Laacher See Volcano (Eifel, Germany), Geophys. J. Int., 216(3), 2025-2036.

Herring, T.A., King, R.W., Floyd, M.A. \& McClusky, S.C., 2018a. Introduction to GAMIT/GLOBK Massachusetts Institute of Technology, Cambridge, Massachusetts. 
Herring, T.A., King, R.W., Floyd, M.A. \& McClusky, S.C., 2018b. GAMIT Reference Manual, GPS Analysis at MIT. Release, 10, 1-168.

Herring, T.A., King, R.W., Floyd, M.A. \& McClusky, S.C., 2015. GLOBK Reference Manual, Global Kalman filter VLBI and GPS analysis program, 10, $1-95$.

Illies, J.H. \& Greiner, G., 1979. Holocene movements and state of stress in the Rhine Graben rift system, Tectonophysics, 52, 349-359.

Johnston, A.C. \& Schweig, E.S., 1996. The enigma of the New Madrid earthquakes of 1811-1812, Annu. Rev. Earth planet. Sci., 24(1), 339384.

Kreemer, C., Blewitt, G. \& Klein, E.C. 2014. A geodetic plate motion and global strain rate model, Geochemistry, Geophysics, Geosystems, 15(10), 3849-3889.

Knöpfler, A., Mayer, M., Heck, B., Masson, F. \& Ulrich, P., 2010. GURN (GNSS Upper Rhine Graben Network) - status and first results, in FIG Congress 2010, Facing the Challenges - Building the Capacity - Sydney, Australia, 11-16 April 2010.

Langbein, J. \& Johnson, H., 1997. Correlated errors in geodetic time series: Implications for time-dependent deformation, J. geophys. Res.: Solid Earth, 102(B1), 591-603.

Langbein, J., 2012. Estimating rate uncertainty with maximum likelihood: differences between power-law and flicker-random-walk models, J. Geod., 86(9), 775-783.

Lutz, S. \& Brockmann, E., 2019. Status report of the Working Group "European Dense Velocities", Geophys. Res. Abstr., 21.

Mao, A., Harrison, C.G.A. \& Dixon, T.H., 1999. Noise in GPS coordinates time series, J. geophys. Res., 104, 2797-2816.

Masson, F., Lehujeur, M., Ziegler, Y. \& Doubre, C., 2014. Strain rate tensor in Iran from a new GPS velocity field, Geophys. J. Int., 197(1), 10-21.

Masson, C., Mazzotti, S., Vernant, P. \& Doerflinger, E., 2019. Extracting small deformation beyond individual station precision from dense Global Navigation Satellite System (GNSS) networks in France and western Europe, Solid Earth, 10(6), 1905-1920.

Maury, J., Cornet, F.H. \& Dobarth, L., 2013. A review of methods for determining stress fields from earthquakes focal mechanisms; application to the Sierentz 1980 seismic crisis (Upper Rhine graben), Bull. Soc. géol. France, 184(4-5), 319-334.

Maury, J., Cornet, F.H. \& Cara, M., 2014. Influence of the lithosphereasthenosphere boundary on the stress field northwest of the Alps, Geophys. J. Int., 199(2), 1006-1017.

Mayer-Rosa, D. \& Cadiot, B. 1979. A review of the 1356 Basel earthquake: basic data, Tectonophysics, 53(3-4), 325-333.

Meghraoui, M., Delouis, B., Ferry, M., Giardini, D., Huggenberger, P., Spottke, I. \& Granet, M., 2001. Active normal faulting in the upper Rhine graben and paleoseismic identification of the 1356 Basel earthquake, Science, 293(5537), 2070-2073.

Métois, M. et al., 2015. Insights on continental collisional processes from GPS data: dynamics of the peri-Adriatic belts, J. geophys. Res.: Solid Earth, 120(12), 8701-8719.

Meyer, B., Lacassin, R., Brulhet, J. \& Mourroux, B., 1994. The Basel 1356 earthquake: which fault produced it? Terra Nova, 6(1), 54-63.

Meyer, W. \& Stets, J., 1998. Junge Tektonik im Rheinischen Schiefergebirge und ihre Quantifizierung, Zietschrift der deutschen geologischen Gesellschaft, 149, 359-379.

Meyer, H., Hetzel, R. \& Strauss, H., 2010. Erosion rates on different timescales derived from cosmogenic $10 \mathrm{Be}$ and river loads: implications for landscape evolution in the Rhenish Massif, Germany, Int. J. Earth Sci., 99(2), 395-412.

Nocquet, J.M., 2012. Present-day kinematics of the Mediterranean: a comprehensive overview of GPS results, Tectonophysics, 579, 220-242.
Peltier, W.R., Argus, D.F. \& Drummond, R., 2015. Space geodesy constrains ice age terminal deglaciation: the global ICE-6G_C (VM5a) model, $J$. geophys. Res.: Solid Earth, 120(1), 450-487.

Rabin, M., Sue, C., Walpersdorf, A., Sakic, P., Albaric, J. \& Fores, B., 2018. Present-day deformations of the Jura Arc inferred by GPS surveying and earthquake focal mechanisms, Tectonics, 37(10), 3782-3804.

Ritter, J.R.R., Jordan, M., Christensen, , U.R. \& Achauer, U., 2001. A mantle plume below the Eifel volcanic fields, Germany, Earth planet. Sci. Lett., 186, 7-14.

Rouland, D., Haessler, H., Bonjer, K.P., Gilg, B., Mayer-Rosa, D. \& Pavoni, N., 1980. The Sierentz southern Rhinegraben earthquake of July 15, 1980: preliminiary results, Developments in Solid Earth Geophysics. Elsevier, 1983, 441-446.

Rozsa, Sz., Mayer, M., Westerhaus, M., Seitz, K. \& Heck, B., 2005a. Towards the determination of displacements in the Upper Rhine Graben Area using GPS measurements and precise antenna modelling, Quat. Sci. Rev., 24, 427-440.

Rozsa, Sz., Heck, B., Mayer, M. \& Seitz, K., 2005b. Determination of displacements in the upper Rhine graben Area from GPS and leveling data, Int. J. Earth Sci., 94, 538-549.

Seiberlich, C.K.A., Ritter, J.R.R. \& Wawerzinek, B., 2013. Topography of the lithosphere-asthenosphere boundary below the Upper Rhine Graben Rift and the volcanic Eifel region, Central Europe, Tectonophysics, 603, 222-236.

Serpelloni, E., Vannucci, G., Anderlini, L. \& Bennet, R.A., 2016. Kinematics, seismotectonics and seismic potential of the eastern sector of the European Alps from GPS and seismic deformation data, Tectonophysics, 688, 157-181.

Schmincke, H.U., Lorenz, V. \& Seck, H.A., 1983. The Quaternary Eifel Volcanic Fields, Plateau Uplift, Springer Berlin Heidelberg, pp. 139-151.

Shipton, Z.K., Meghraoui, M. \& Monro, L., 2016. Seismic slip on the west flank of the Upper Rhine Graben (France-Germany): evidence from tectonic morphology and cataclastic deformation bands. In Landgraf, A., Küebler, S., Hintersberger, E. \& Stein, S.eds, 2017. Seismicity, Fault Rupture and Earthquake Hazards in Slowly Deforming Regions. Geological Society, London, Special Publications, Vol. 432, pp. 147-161.

Tesauro, M., Hollenstein, C., Egli, R., Geiger, A. \& Kahle, H.G., 2006. Analysis of central western Europe deformation using GPS and seismic data, J. Geodyn., 42(4-5), 194-209.

Williams, S.D.P, 2008. CATS: GPS coordinate time series analysis software, GPS Solut., 12, 147-153.

Wu, P. \& Johnston, P., 2000. Can deglaciation trigger earthquakes in N. America? Geophys. Res. Lett., 27(9), 1323-1326.

Ziegler, P.A., 1992. European Cenozoic rift system, Tectonophysics, 208, 91-111.

\section{SUPPORTING INFORMATION}

Supplementary data are available at $G J I$ online.

\section{Supplements-Henrion-2020.zip}

Please note: Oxford University Press is not responsible for the content or functionality of any supporting materials supplied by the authors. Any queries (other than missing material) should be directed to the corresponding author for the paper. 